\title{
Nem privado nem estatal: em busca de uma nova estratégia para a provisão de serviços públicos
}

\section{Introdução}

\subsection{A crise do Estado e a precarização dos serviços sociais}

Depois de três décadas em que o Estado cumpriu o papel de promotor da prosperidade econômica e social, adotando políticas econômicas de inspiração keynesiana, acompanhadas, nos países desenvolvidos, da formação do Estado de Bem-Estar e, nos países em desenvolvimento, de um Estado desenvolvimentista com razoável proteção social, esse padrão entrou em decadência. A partir da crise econômica mundial da década de 70, a crise do Estado contemporâneo passou a se manifestar com clareza crescente nas suas três dimensões: crise fiscal, crise de governabilidade e crise de governança.

Com a queda no ritmo de crescimento econômico e o aprofundamento da recessão ao longo dos anos 80 , a crise fiscal, que já era evidente do lado da despesa, em decorrência de décadas de políticas públicas de bem-estar social financiadas com fundos públicos, ganha contornos bem definidos também do lado da receita, em função da queda da arrecadação tributária. Poucos recursos de um lado e muitos compromissos de outro fizeram brotar e firmar a idéia de que as demandas sociais tinham se acumulado em um volume para o qual o modelo de provisão estatal de serviços públicos não oferecia mais capacidade de resposta.

Na medida em que programas e promessas de campanha não eram cumpridos, que a capacidade política de governar caía em descrédito, a crise de governabilidade do Estado contemporâneo alargava-se. Os aparelhos estatais, estruturados burocraticamente, não conseguiam
Diretor de

Administração e

Finanças da ENAP, mestre em Administração Pública pela FGV São Paulo e especilalista em Políticas Públicas e Gestão Governamental 
implementar as decisões políticas tomadas pelos governos, mostrando-se incapazes de superar a situação de escassez e a ineficiência da sua própria organização. Na década de 90 , esta crise de governança cristalizase em três faces: uma financeira, ligada ao déficit das contas públicas; outra, administrativa, decorrente da ineficiência do modo burocrático de administrar as organizações estatais; e uma terceira, estratégica correspondente ao modo inadequado de intervenção do Estado nas atividades sociais e econômicas.

A execução das políticas públicas de saúde, de educação, de assistência e previdência social, de proteção ao meio ambiente, de combate ao desemprego e de apoio à cultura são atividades que ao mesmo tempo respondem a direitos sociais e produzem importantes externalidades positivas. Por essas razões deveriam ser de acesso universal. Ocorre que o mercado oferece esses serviços de forma incompleta, porque a iniciativa privada não consegue otimizar seus ganhos, atendendo a totalidade da demanda da sociedade. Em razão das falhas de mercado, de um lado, e da importância política e econômica destas atividades para o conjunto da sociedade, do outro, o Estado entra na provisão desses serviços. Entretanto, a crise do Estado contemporâneo, sobretudo nos aspectos fiscal e da ineficiência das organizações burocráticas públicas, levou os governos a rever as políticas de bem-estar, de que resultou a precarização dos serviços sociais.

O esforço de superação da crise do Estado vem-se traduzindo, quando se trata de rever a forma de intervenção do Estado no desenvolvimento social, na redefinição do modo de financiamento e da maneira de organizar a execução das políticas públicas sociais, de modo a garantir efetividade na resposta às demandas sociais e maior eficiência na produção dos serviços. Quando examinamos as alternativas que se apresentam para reordenar a intervenção estatal, verificamos que são três as possíveis formas de organizar a provisão de serviços e atividades que envolvem externalidades positivas importantes e asseguram direitos sociais. A primeira é a que se faz diretamente através das organizações estatais, que é justamente a maneira associada à crise de governança que precisa ser superada ${ }^{1}$. A segunda é deixar que o mercado regule a prestação dos serviços, privatizando ou terceirizando, que é a alternativa de minimizar o Estado, tentada por governos conservadores, que não produziu os resultados esperados ${ }^{2}$, sobretudo no plano social. A terceira é a desestatização, mantendo o caráter público dos serviços; trata-se de modalidade em que o Estado financia as políticas sociais através de instituições públicas não pertencentes ao Estado, nem à esfera privada ${ }^{3}$.

Cada vez mais, organizações que não são nem do Estado, nem do setor privado, prestam serviços sociais de caráter público. Em geral são 
organizações sem fins lucrativos, atuando em atividades relacionadas com os direitos sociais dos cidadãos, e expressam a vitalidade da sociedade civil ao ocupar os espaços vazios deixados pelo mercado e pelo Estado. Essas organizações têm uma diversidade muito grande de formas e nomes — organizações não-governamentais, associações comunitárias, organizações religiosas, fundações privadas, entidades assistenciais - e prestam serviços também muito diversificados quanto à extensão e o público que alcançam - serviços educacionais básicos, intermediários e universitários, técnicos e especializados, serviços de saúde preventivos e hospitalares, serviços assistenciais e culturais variadíssimos ${ }^{4}$. No seu conjunto essas formas organizativas constituiriam o que Salamon (1992:15) chama de terceiro setor:

"Embora a terminologia utilizada e os propósitos específicos a serem perseguidos variem de lugar para lugar, a realidade subjacente é bem similar: uma virtual revolução associativa está em curso no mundo, a qual faz emergir um terceiro setor".

A participação dessas organizações nos serviços sociais no Brasil é muito expressiva. Segundo os dados tabulados por Rubem César Fernandes ${ }^{5}, 40 \%$ delas se ocupam de educação e formação, 30\% de desenvolvimento e promoção social, mais de $20 \%$ com saúde, e $15 \%$ com pesquisa. Dados do mesmo levantamento dão conta de aproximadamente mil ONGs registradas nos diretórios de ONGs latino-americanas ${ }^{6}$. Dados mais recentes da $\mathrm{ABONG}^{7}$ registram em torno de 2 mil organizações, reconhecidas como as que se enquadram no perfil definido por essa entidade, atuando somente no Brasil. Estimativas, que partem de critérios mais liberais de definição de organizações voltadas para os interesses gerais da sociedade, chegam a 17 mil.

Não estamos diante apenas de quantidades significativas, mas de qualidade socialmente reconhecida e de importância cultural inquestionável. Tomando alguns exemplos esparsos, podemos alinhar, no caso do Brasil, algumas instituições de grande prestígio nacional que se enquadram no terceiro setor, como a PUC / Pontifícia Universidade Católica e a Fundação Getúlio Vargas, na área de ensino, as Santas Casas de Misericórdia, na área da saúde, o IBASE, na ação social e o SOS Mata Atlântica, na proteção ambiental ${ }^{8}$. Na Inglaterra, os Quangos/Quasi Non Governamental Organizations, sociedades civis que passaram a receber recursos orçamentários do governo inglês; os museus na Holanda; nos EUA, as chartered schools, escolas comunitárias financiadas com recursos públicos, e as escolas primárias na Espanha.Todas elas, exemplos de organizações não- governamentais que assumiram um papel institucional de grande relevância social. 


\subsection{Organizações públicas não-estatais; emergência de um novo modo de prover serviços públicos?}

O caso das escolas primárias na Espanha é um bom exemplo de estratégia inovadora na execução de políticas sociais, na qual o Estado desempenha um novo papel, em função da emergência de uma nova esfera de relações societárias impulsionada pela multiplicação das organizações públicas não-estatais. O governo Felipe Gonzalez encontrou, ao assumir, dois milhões de crianças de um total de oito, estudando em escolas pagas. Como a Constituição espanhola determina que todo o ensino primário deve ser gratuito, o então ministro da Educação José Maria Maraval assumiu o desafio de fazer cumprir aquele direito. Superados os obstáculos que se opunham ao projeto, o Estado passou a financiar as escolas comunitárias e religiosas que já prestavam os serviços de educação básica, remunerado-as com base no custo médio por aluno das escolas públicas ${ }^{9}$.

A lição mais importante, que podemos extrair desta ação, não é a de que as Constituições devem ser respeitadas, mas a de como superar problemas que impedem que os direitos sociais previstos constitucionalmente se cumpram. Este exemplo nos ensina como é possível romper com uma visão dicotômica da relação entre o público e o privado, que no mais das vezes não permite que se aproveite as potencialidades apresentadas pela sociedade. Havia uma situação-problema - oferecer estudo básico, gratuito e universal, com recursos escassos - e havia uma solução potencial - os investimentos, materiais e humanos, feitos pelas escolas comunitárias e religiosas. Faltava a criação de uma nova esfera de relações entre o Estado e a sociedade: a esfera pública não-estatal, na qual pudessem se reorganizar os recursos do Estado e da sociedade para atender as demandas reprimidas da população.

A importância da construção e consolidação de novas arenas de relações públicas não-estatais, a partir da emergência e afirmação do terceiro setor, está na possibilidade de se vir a ter uma equação viável para prover os serviços sociais e executar políticas sociais, capazes de superar os obstáculos que as soluções, através do Estado ou do mercado, apresentam.

Caso tivéssemos de contar somente com os dois instrumentos clássicos do desenvolvimento econômico e social, o mercado e o Estado, possivelmente estaríamos em uma situação embaraçosa. O mercado já se mostrou incapaz de regular a produção e a distribuição de bens que correspondem a conquistas de direitos sociais. O Estado esgotou sua capacidade de expandir os investimento sociais. Sem mercado e sem Estado, $o$ atendimento das demandas sociais tenderiam a ter uma existência pendular de avanços e retrocessos, ao sabor das tensões políticas e 
econômicas. A emergência de organizações públicas não-estatais pode ser vista como uma saída viável para esse problema? Esta pergunta não é original; vem sendo feita e analisada por um número crescente de estudiosos, governantes e atores da sociedade civil, mas também não é trivial, porque é um dos capítulos da reforma do Estado contemporâneo, sobre o qual há menos conclusões.

À primeira vista, parece haver convergência entre a tendência espontânea da sociedade em se auto-organizar para prestar os serviços sociais que lhe faltam e a proposta de publicização ${ }^{10}$, que vem surgindo pelo lado do Estado. Além de atacar o problema da precariedade dos serviços públicos ${ }^{11}$, esta convergência traria benefícios adicionais para questões específicas de cada lado. Para o Estado, representaria a possibilidade de equacionar o problema da crise de governança e a oportunidade de criar um ambiente competitivo na prestação de serviços públicos, afastando-se, dessa forma, da armadilha do monopólio. Para a sociedade civil organizada, seria a chance de avançar na participação política e no controle social.

\subsection{Objetivos e elementos de análise}

Meu intuito neste artigo é discutir os aspectos estratégicos envolvidos na emergência de uma terceira via para a provisão de serviços públicos sociais, frente à crise de governança, concentrando a análise nas formas pelas quais o Estado e a sociedade se organizam para intervir no campo das políticas públicas sociais. O pressuposto que está por trás deste objetivo é o de que há algo novo na produção de bens públicos, que não por acaso se revigora em meio à crise do Estado contemporâneo. Pretendo ficar no círculo das mudanças institucionais, que venham afetar a relação entre Estado e sociedade, tendo por referência a propriedade (pública, estatal ou privada). Por essa razão, não trataremos do tema da descentralização político-administrativa, a partir da qual alternativas de solução para a problemática da precarização das condições sociais também são discutidas. São abordagens que não necessariamente precisam se cruzar ${ }^{12}$. O objetivo nesse caso é examinar a forma mais eficiente e democrática de organizar os serviços sociais, no contexto da reforma do Estado.

A análise destas questões apoiou-se em elementos teóricos e empíricos da literatura recente sobre a rearticulação das relações entre o Estado e a sociedade: as propostas de reforma e reconstrução do Estado e o desenvolvimento do terceiro setor. Embora as referências teóricas sejam quase sempre internacionais, as referências empíricas concentramse na experiência brasileira. A bibliografia na área de administração pública trata com assiduidade dos temas da crise de governança, da publicização e da contratualização, e cobre, dessa forma, o problema, a estratégia e a instrumentalização das alternativas de provisão dos serviços 
sociais. Outro aspecto importante na sistematização da análise foi a tentativa de delimitar as áreas de atuação do Estado e da sociedade nessas atividades.

O estudo se desenvolveu, iniciando-se pela análise das possíveis repercussões sobre a provisão de bens e serviços sociais das duas grandes famílias de estratégias: a privatizadora neoliberal e a reformadora gerencialista, desenvolvidas para tirar o Estado da crise. Um segundo capítulo trata de caracterizar as organizações não-estatais segundo a concepção da reforma gerencialista, e desdobra-se no exame de uma possível terceira via para resolver o problema da provisão de serviços sociais, que se distingue da alternativa por dentro do Estado, ao propor o aprofundamento da estratégia de publicização a partir da emergência de organizações não-estatais, geradas por iniciativa da sociedade. Na conclusão, busca-se fazer um balanço das vantagens e dos problemas da terceira via, e recomendar alguns cuidados a tomar, ao se trilhar esse caminho.

\section{Provisão de serviços sociais: estratégias para sair da crise}

A crise do Estado Social ${ }^{13}$, dos anos 80 , foi enfrentada com algumas medidas que adquiriram rapidamente consenso geral. Ajuste fiscal e abertura comercial para o exterior, com variações nos prazos e nos métodos, foram providências adotadas, na sua essência, por praticamente todos os países. As distintas visões de como enfrentar a crise entraram em choque, quando se tratou de explicitar como deveria ser o novo Estado que iria substituir os modelos superados. Uma grande divisão se estabeleceu. De um lado, alinharam-se as propostas de inspiração liberal e conservadora, designadas genericamente de neoliberais, que viam no retorno ao Estado liberal do século XIX, restrito às funções de garantir os contratos entre particulares e a defesa nacional, a melhor solução para superar a crise. Os liberais apostavam que junto com a supressão das funções sociais e econômicas do Estado, desapareceriam seus problemas, sobretudo a crise fiscal e a ingovernabilidade. Esta postura radical inicial, mais teórica do que prática, foi substituída por alternativas mais brandas, como a descentralização das políticas sociais e a focalização das ações do Estado nos grupos sociais mais pobres. De outro lado, alinharam-se as propostas de reforma e reconstrução do Estado, que reconheciam a necessidade de rever o tamanho e o papel do Estado, sem abrir mão de assegurar direitos sociais e bens públicos, enfatizando suas funções de regulação e financiamento. 


\subsection{A via privatizadora}

O caminho da privatização teve grande repercussão, ao contribuir decisivamente para o equilíbrio das contas públicas e por encontrar no setor privado os capitais e a competência para adquirir, investir e sanear as empresas estatais produtoras de bens e serviços para o mercado. Revistas e jornais ao alcance do público estamparam o êxito das privatizações nos setores energético, de telecomunicações, petrolífero, transportes e na indústria de base ${ }^{14}$.

No campo da infraestrutura, também privatizou-se em larga escala, mais através das concessões, do que de vendas. A privatização nesse caso não produziu entrada de recursos, mas possibilitou novos investimentos e, portanto, economias futuras com o pagamento de empréstimos. Desta maneira, serviços de saneamento básico, captação e distribuição de água, transporte rodoviário, conservação de estradas passaram da forma estatal de produção para a esfera privada de provisão.

Embora não se possa afirmar que essa passagem tenha ocorrido sempre de forma tranqüila, pode-se dizer que os argumentos pessimistas que previam sérios problemas com a transferência, não se concretizaram. O oposto aconteceu. Vantagens para os Estados, que reuniram importantes recursos financeiros para amenizar o déficit público, equacionaram parte da crise fiscal, reduziram gastos públicos com o fim dos subsídios, reduziram a remuneração indireta de pessoal e aumentaram a arrecadação de impostos. Vantagens para os usuários e clientes, que, quase sem exceção, passaram a receber produtos e serviços melhores, a menores preços e com garantia de fornecimento. Vantagens para o setor privado, que na maior parte das vezes adquiriu, junto com capital e estoque, monopólios naturais, que, mesmo fiscalizados, representam uma forma segura de maximizar lucros, especialmente em mercados com demanda fortemente reprimida.

O calcanhar de Aquiles dos defensores da via privatista tem sido os serviços públicos sociais. Não que nestes setores também não haja grandes ineficiências, desperdícios e incapacidades que possam ser transformados em lucros. Há, e muitos. Entretanto, uma vez conquistados os primeiros ganhos de eficiência, as taxas de lucro passam a cair na mesma proporção que diminui a renda da população atendida. O resultado é a tendência a que estes mercados sejam atendidos de forma incompleta, deixando uma grande parcela de potenciais consumidores desatendida. A América Latina foi pródiga em criar casos clássicos de fracasso nas tentativas de desregulamentação e privatização de serviços públicos. Ademais, bens e serviços públicos socialmente reconhecidos como direitos dos cidadãos encontraram, na oposição organizada pelos movimentos de cidadãos, forte barreira política à privatização. 
A variante da terceirização também não produziu bons resultados na área social. A contratação de empresas privadas, atraídas inicialmente pelas vantagens de um possível mercado cativo, mas que logo perceberam que não poderiam equilibrar-se financeiramente com os preços pagos pelos governos, não produziu estímulos suficientes para a sustentação dessa estratégia no campo social. Quase sempre o equacionamento econômico foi conseguido às custas de serviços de baixa qualidade.

A terceirização generalizou-se nos serviços públicos federais, estaduais e municipais nas áreas de apoio, como limpeza, manutenção de prédios, manutenção de cadastros e outros serviços administrativos, como observa Carvalho Neto (1996:100). Mas a repercussão na diminuição do déficit fiscal foi muito pequena. Em alguns casos, a terceirização sequer representou uma economia direta, mas uma tática para evitar aumentos de gastos futuros com os servidores públicos ${ }^{15}$. E o impacto sobre a qualidade dos serviços prestados só foi sentido de forma positiva, onde o controle social é forte.

Em resumo, a privatização caminhou bem no caso dos bens e serviços relacionados com as condições de reprodução do capital, e não produziu bons resultados no caso das condições de reprodução da força de trabalho. Tomando por base a classificação adotada pelos especialistas do Banco Mundial, que apontam para a importância estratégica dos investimentos em políticas sociais, a partir da divisão do capital das sociedades em quatro tipos: natural, produtivo, humano e social, a conclusão a que se chega é que o setor privado não consegue desenvolver os dois últimos tipos, e protege muito mal o primeiro.

Até mesmo o mais renitente adepto das convicções liberais reconhece que as externalidades positivas e as vantagens competitivas derivadas dos gastos com educação, saúde pública, pesquisa científica e cultura são fundamentais para o progresso econômico, e, por isso, sua oferta não pode ser decidida exclusivamente pelos mecanismos de mercado.

Como já foi mencionado, as experiências liberais de reforma adotaram estratégias de descentralização e focalização para diminuir o impacto negativo da retração do Estado na provisão de serviços sociais. Porém, hoje há mais dúvidas, do que apoio, a estas formas de enfrentar o problema, sobretudo porque o diâmetro do foco pode estreitar-se a ponto de excluir parcelas da população que não teriam acesso aos serviços sociais, sem a intervenção do Estado, e a descentralização torna-se uma maneira de transferir o problema para outras esferas de governo, igualmente incapazes de resolvê-lo. Com o fracasso da via privatizadora no campo das políticas socais, observa-se atualmente a predominância da via reformadora, tanto como corrente propositiva, como em experiências concretas dentro do Estado, através de reformas administrativas, cuja 
matriz teórica é a tese do paradigma pós-burocrático, como sendo o caminho acertado para resolver os problemas da crise de governança ${ }^{16}$. Na visão de Bresser Pereira (1997:11), para levar a termo a reforma do Estado será preciso:

"o aumento da governança do Estado, ou seja, da sua capacidade de tornar efetivas as decisões do governo, através do ajuste fiscal — que devolve autonomia financeira ao Estado - da reforma administrativa rumo a uma administração pública gerencial (ao invés de burocrática) e da separação, dentro do Estado, ao nível das atividades exclusivas de Estado, entre a formulação de políticas públicas e a sua execução".

\subsection{A via reformadora}

O problema da provisão de bens e serviços públicos voltou às mãos do Estado, como o "mico" do jogo de baralho, não pela vontade do jogador, mas pelo fato de que ninguém quer ficar com ele. Mais porque o problema não encontrou solução na esfera privada, do que por firmeza de convicção política no acerto da via estatal ${ }^{17}$. O que não quer dizer que não haja diferenças fundamentais entre privatistas e reformistas. Os privatistas procuram soluções paliativas para os problemas sociais, procurando reduzir ao mínimo o envolvimento do Estado, cujo corolário é reduzir o Estado ao mínimo. Os reformadores buscam alternativas dentro ou fora do Estado, porque não abrem mão de atribuir ao Estado a responsabilidade política sobre o futuro da sociedade. E aí, o tamanho do Estado deixa de ser uma questão de princípio para ser uma das conseqüências das estratégias adotadas.

A tese do paradigma pós-burocrático, na prática denominada também de gerencialismo ${ }^{18}$, propõe-se a encontrar respostas para os problemas da provisão de serviços públicos, e em particular dos serviços sociais, a partir de mudanças na organização e no funcionamento do aparelho burocrático do Estado.

Um dos eixos de mudança da via reformadora gira em torno de novas práticas e estruturas voltadas para a eficiência, a produtividade e a redução de custos. Tem, como requisito, o rompimento com as regras e procedimentos uniformes e gerais do modo burocrático de administrar e a adoção de práticas gerenciais da esfera privada. Um segundo eixo se assenta sobre a redefinição dos objetivos das organizações estatais. Procura quebrar a noção de que o principal compromisso dessas organizações é com o estrito cumprimento de normas, e que a partir dele devem ser avaliadas. No seu lugar coloca a avaliação de resultados medido em valor para o usuário, como o critério de bom desempenho a ser perseguido. Um terceiro eixo separa a formulação de políticas da provisão dos serviços, ou da execução de programas, como condição para criar um 
espaço de concorrência e relações contratuais entre os financiadores, os consumidores e os provedores dos serviços.

Há uma engrenagem única unindo estes três eixos. Embora o mercado não se interesse pela totalidade do setor constituído pelos serviços sociais — o que os aproxima do conceito de bem público de Stiglitz ${ }^{19}$ - algumas características destes bens e serviços são muito próximas dos bens privados; são divisíveis, seu custo marginal de provisão é relativamente baixo, e é possível excluir consumidores. A solução engenhosa para resolver este paradoxo (bens privados, de interesse público, desprezados pelos produtores privados) foi criar uma forma privada de produzir os serviços, transformando organizações estatais em fac-símiles das organizações privadas e organizando um quase-mercado, uma quase-concorrência ${ }^{20}$. A função desta simulação é transferir os atributos virtuosos da produção privada (competição, efetividade, eficiência e qualidade), voltada para o mercado, para a produção dos bens e serviços sociais, voltados para o interesse público.

Mas este é apenas um lado da moeda do problema macroorganizacional que a reforma gerencialista se propõe a enfrentar. Do outro lado está o problema do equacionamento da responsabilidade social do Estado para com o cidadão. A produção para o mercado tem como critério último o equilíbrio entre o interesse do comprador e o do produtor. Havendo equilíbrio, há consumo, há produção e há mercado. Não havendo, a tendência é que o mercado apresente falhas. Mesmo que as organizações desestatizadas produzissem segundo os métodos otimizadores das empresas privadas, isto não seria suficiente para garantir o equilíbrio entre o interesse delas e o do conjunto dos cidadãos. Porque embora um lado queira consumir, o outro só produzirá a quantidade e qualidade demandadas, se não depender do equilíbrio de preços para otimizar seus ganhos. Em outras palavras, estas organizações só produziriam nas quantidades demandadas pelo conjunto dos cidadãos, se fossem subsidiadas com recursos públicos ${ }^{21}$.

A reforma gerencialista propõe, como estratégia para descentralizar serviços públicos, mantendo a responsabilidade financeira e regulatória do Estado, a criação de novos tipos de organizações, que vêm recebendo nomes variados dependendo da finalidade a que se destina: agência autônoma, organização social, agência executiva, fundação de serviços públicos, agência pública. O molde comum a todas essas designações é a de organização não-estatal, nem privada, sem fins lucrativos, cuja finalidade é a de executar serviços de interesse público, de natureza concorrencial, com financiamento público e métodos de funcionamento do setor privado, submetida a triplo controle: estatal, social e de mercado. 
As críticas a esse modelo têm sido: a) na prática, por terem sido criadas pelo Estado e a partir do Estado, essas organizações mantêm os mesmos vícios administrativos e traços culturais de quando pertenciam ao aparelho estatal, continuam lentas e seus ganhos de eficiência ficam muito abaixo do esperado; b) o controle social não funciona, a representação da sociedade tende a se tornar formal, e a assimetria de informações entre os executores e os controladores permanece quase tão forte como antes; c) o processo de desestatização por essa via é muito lento e não atende a velocidade em que as mudanças devem ser feitas; d) a concorrência entre as organizações não funciona, porque a qualificação atende a critérios corporativistas e aos interesses de grupos burocráticos já constituídos e consolidados no aparelho de Estado; e) as resistências à mudança a partir da extinção de organizações estatais é muito grande devido às perdas de segurança no emprego, de privilégios e oportunidades de trade-offs entre políticos e burocratas; f) os dirigentes e empregados das organizações estatais tendem a rejeitar a troca de mais autonomia por controle de resultados.

\subsection{A terceira via: aprofundar a publicização.}

Enquanto conservadores e reformistas disputam a hegemonia de suas teses no campo ideológico e político; da sociedade civil, emergem novas formas de organização da ação social que, passando ao largo da forma estatal e da iniciativa privada, atacam o problema das demandas sociais diretamente no espaço público em que elas se formam. A democratização da sociedade fez com que surgisse e se consolidasse uma nova esfera de relações sociais, que contendo uma grande diversidade de atores, rompe com a dicotomia, teórica e prática, formada pelo Estado, de um lado, e o mercado, do outro. Diversidade e inovação são as marcas desta esfera de relações societárias. Segundo Portantiero (1989:57), o espaço público democrático é geneticamente plural. Nele as formas de gestão diversificam-se em autogestão, co-gestão, cooperativização. As formas de tomada de decisão multiplicam-se em: socializadas, descentralizadas e autonomizadas. A gerência apresenta-se em variadas formas: desburocratizada, transparente e participativa.

Enquanto a crise do Estado repercutia nas organizações burocráticas estatais na forma de crise de governança, e se traduzia em termos práticos na incapacidade crescente de prestarem os serviços sociais demandados pela população, crescia a importância das organizações nãogovernamentais, tanto na provisão, como no controle social sobre a ação governamental. As ações voltadas para a defesa de interesses comunitários, através de associações auto-gestionadas, não constitui uma novidade. 
Em maior ou menor grau, variando com a particularidade histórica de cada configuração social, elas fazem parte do repertório político das sociedades contemporâneas. O associativismo tem, em muitos países, forte tradição de ação na esfera pública, independente da participação do Estado na resposta às demandas sociais. A novidade está na vitalidade que as sociedades estão demonstrando ao criar uma rica multiplicidade de organizações em meio à crise do Estado.

Embora esse vigor seja mais evidente no Hemisfério Norte, em praticamente qualquer quadrante mundial, as organizações não-governamentais, a partir de meados da década de 70 , cresceram a taxas muitos superiores do que em qualquer período anterior ${ }^{22}$. Outro aspecto relevante deste surto recente é o reconhecimento e a legitimidade que estas organizações adquiriram junto à sociedade e aos governos. Um terceiro aspecto, que tem valor crucial para o futuro das relações da sociedade com o Estado, é que essas formas associativas criam, ao se condensarem em uma teia de relações, uma nova arena de relações sociais e políticas: o espaço público não-estatal. Um quarto ponto notável é a capacidade de articulação política combinada com a capacidade de prestar serviços sociais com alto grau de efetividade e eficiência ${ }^{23}$. Um quinto aspecto é o da diversidade e adaptabilidade; a diversidade refere-se à pluralidade interna das organizações e a adaptabilidade à flexibilidade das estruturas organizacionais.

Este conjunto de associações e organizações recebe uma variedade de nomes e de definições: terceiro setor, setor não-governamental, setor sem fins lucrativos. Neste estudo adoto os mesmos termos e definições cunhados por Bresser Pereira, qual seja, o de setor público nãoestatal; formado por organizações públicas não-estatais - OPNEs, assim caracterizadas pelo fato de que o motor de suas ações é o interesse público, e não-estatais porque não fazem parte do aparelho do Estado. Alternativamente usaremos a definição de terceiro setor, porque expressa com precisão o fato de estarmos diante de uma terceira forma de propriedade, distinta da estatal e da privada. Tanto uma como outra englobam a expressão "não-governamental", com a vantagem de serem mais precisas. Quanto à definição "sem fins lucrativos", seria redundante, porque, por definição, as entidades públicas não têm fins lucrativos.

Bresser e Grau distinguem três tipos de OPNEs: as organizações de auto-ajuda; as organizações não-governamentais e as fundações de serviço público, desestatizadas. As primeiras são organizações comunitárias, baseadas no trabalho voluntário, de ação direta sobre as demandas e carências populares. As ONGs apresentam um grau de organização mais permanente e elaborado, e acrescentam as funções de interlocução e de organização política da população, além de incluirem a prestação de 
serviços sociais. As fundações desestatizadas fazem parte da estratégia

de descentralização administrativa, das recentes reformas administrativas encaminhadas por governos que adotaram a via reformadora ${ }^{24}$.

Em seu estudo "Ampliando o conceito de não-governamental", Covarrubias (1992) distingue três tipos de organizações públicas não-estatais: as ONGs ${ }^{25}$, as organizações privadas subvencionadas e as organizações de base, reunindo-as sob a denominação de Organizações Privadas de Desenvolvimento Social — OPDS ${ }^{26}$. Entendo que este não é um nome feliz, porque destaca o caráter privado destas organizações, que as associa às iniciativas privadas para o mercado, enquanto que elas dirigem-se basicamente para o interesse público.

Descendo a um nível mais detalhado de classificação, Mantilla (1992) ${ }^{27}$ entende que o termo ONGs pode incluir uma grande variedade de instituições, como: os grupos recreativos; as instituições de caridade; as associações profissionais; os sindicatos e os clubes. Classifica-as, utilizando três critérios: segundo o financiamento, entre doadoras e receptoras ${ }^{28}$; segundo a atividade, em assistenciais e consultivas; e ainda segundo a distribuição geográfica, em internacionais, nacionais e locais. Nogueira (1992:49) estabelece uma tipologia das ONGs, dividindo-as em organizações que perseguem modelos alternativos de relações sociais, voltadas para a auto-suficiência, resistência e enfrentamento ao Estado, e as organizações voltadas para a profissionalização e a formalização de metodologias.

Salamon (1996) e Fernandes (1994) apresentam classificações que refletem preocupações mais abrangentes, nas quais incluem as organizações da sociedade civil, cujo objetivo principal é enfrentar o problema do financiamento das políticas sociais, seja através de coleta de doações, seja pela cobrança parcial dos serviços que prestam.

Salamon dá o nome de Nonprofit Organizations - NPO para o que estamos chamando de OPNEs e as tipifica em quatro categorias:

1. Funding agencies. Em geral fundações privadas, cujo objetivo principal, quando não o único, é o de levantar recursos e canalizá-los para organizações que prestam serviços sociais (Blue Cross, Ford etc.).

2. Member serving organizations. Existem para prover bens e serviços para seus membros, e não para a sociedade como um todo. (Entidades profissionais, sindicatos, cooperativas, sociedades de ajuda mútua e similares).

3. Public benefit organizations. Cuja finalidade é servir aos necessitados ou ao bem-estar geral (instituições educacionais, culturais, agências de bem-estar, nursing homes, hospitais etc.).

4. Religious congregations. Organizações dedicadas essencialmente a funções religiosas e sacramentais. 
Rubem César Fernandes, no livro Público porém privado, define o terceiro setor como aquele em que agentes privados visam a produção de bens públicos ${ }^{29}$.Classifica as organizações deste setor em 4 grandes grupos: a) as formas tradicionais de ajuda mútua, de caráter marcadamente assistencial; b) os movimentos sociais e associações civis, dedicados ao "trabalho de base", feito junto às comunidades, a partir de problemas sociais que afetam o cotidiano dos cidadãos; c) as ONGs, expressão mais apurada do "setor privado com funções públicas", dedicadas a desenhar estratégias e políticas para atender demandas socioculturais das associações comunitárias e dos movimentos sociais, que não são satisfeitas, nem pelo mercado, nem pelo Estado; d) a filantropia empresarial que, ainda incipiente na América Latina (Fernandes, 1992), vem crescendo na última década, junto com a afirmação da democracia social.

Analisando as várias taxonomias desenhadas por esses autores, cheguei à conclusão que uma boa classificação funcional e conceitualmente adequada separaria as organizações públicas não-estatais em quatro grandes grupos:

a) Organizações de base - OB;

b) ONGs;

c) OPNEs de serviço continuado;

d) OPNEs financiadoras.

Estas quatro categorias agrupam-se em duas gerais. Na primeira, estariam as organizações dedicadas a levantar fundos para financiar atividades de apoio social: fundações privadas, empresariais ou religiosas. A segunda grande categoria engloba as organizações voltadas direta ou indiretamente para a provisão de serviços e bens públicos, que não cobram dos usuários o custo total dos serviços que prestam. Neste grupo incluem-se as organizações de base, as associações comunitárias, os movimentos sociais, as organizações não-governamentais de todos os tipos e uma categoria pouco explorada na sua especificidade pela maior parte dos estudiosos, as organizações que prestam serviços continuados, em geral, de saúde, educação, pesquisa e culturais, que muito se assemelham operacionalmente com os serviços estatais, junto às quais estariam reunidas por sua similitude, as fundações desestatizadas a que se referem Bresser Pereira e Cunill Grau.

Para Bresser, o caráter estratégico das ONGs está na sua característica de organizações vocacionadas e de think tank; são organizações com uma visão de futuro e projeto político. Mas podem ser vistas também como reserva de capacidade profissional e de formação de agentes públicos. Neste sentido há dois aspectos também estratégicos a considerar: elas servem para complementar salários de pessoas vocacionadas para o serviço público, que por diversas razões estão fora do âmbito estatal, e oferecem a oportunidade de acúmulo de experiência prática ${ }^{30}$. 
Durante o período autoritário, o trabalho nas comunidades de base animava as pessoas que lutavam pela democracia e tinham um compromisso com o interesse público. Pensar em formar uma ONG só passou a ser parte do projetos destas pessoas depois da abertura democrática, sobretudo porque, ao procurar atuar através do Estado, aprenderam que o aparelho burocrático era um sério entrave aos avanços que queriam imprimir às política públicas ${ }^{31}$. Também não viam a administração pública como um instrumento democrático, mas submetido ao clientelismo e ao patrimonialismo; inadequada portanto para levar adiante os projetos de políticas públicas que haviam sido gerados e experimentados nas organizações de base, de forma participativa e inovadora. A ONG desta época foi criada para resolver os problemas das amarras burocráticas do lado do poder público, e do espontaneísmo e amadorismo, das organizações de base.

$\mathrm{O}$ que diferencia uma ONG de uma OB, entre outras coisas, é a mudança de abordagem dos problemas sociais. As ONGs correspondem a uma passagem da assistência de emergência executada pelas OB, para a assistência permanente, e do enfrentamento de problemáticas pontuais para o enfrentamento de problemas gerais ${ }^{32}$. Ao invés de centrarem-se na defesa social imediata, ela centra-se na formulação e na articulação da execução de políticas públicas ${ }^{33}$. Outra distinção importante é que enquanto as OB são criadas para defender, quase sempre de forma exclusiva, seus próprios membros, as ONGs voltam-se para a defesa dos grupos sociais precarizados, fora de seus membros ${ }^{34}$.

As ONGs distinguem-se entre as OPNEs pela abordagem centrada na organização e mobilização dos grupos sociais para o auto-desenvolvimento, independência e autonomia , melhoria no uso dos recursos disponíveis, criação de novos recursos, promoção da eqüidade e redução dos níveis de pobreza, para influenciar os governos e influir na formação de novas instituições, novas arenas e novas agendas públicas, voltadas para a superação da pobreza. Enquanto que as OPNEs de "serviço continuado", permanente e regular, distinguem-se das ONGs e das OBs pelo seu caráter de longo prazo e seu comprometimento institucional com as políticas sociais.

Nem todas as ONGs podem adaptar-se às funções de prestação continuada de serviços sociais, mas a conclusão de que somente as organizações desestatizadas e as grandes OPNEs consolidadas de serviços continuados poderiam cumpri-las a contento, pode ser precipitada. Há muitas OPNEs de serviços continuados emergentes, a exemplo de vários hospitais ligados a Faculdades de Medicina financiados por planos de saúde, instituições de educação esportiva, escolas, centros de saúde comunitários etc. Assim como há uma transição 
entre as OBs e as ONGs, há também uma transição entre as ONGs e as OPNEs de serviços continuados, que não pode ser desconsiderada nesta análise. Em suma, mesmo que se conclua como faz Salamon, que as public benefit service organizations (similares, na sua definição, às OPNEs de serviço continuado) são as organizações capazes de promover o bem-estar e o interesse público de forma profunda e duradoura, em cooperação com o Estado, devemos considerar as possibilidades que instituições pertencentes a outras categorias têm de exercer o mesmo papel, com igual eficiência e, eventualmente, vantagens decorrentes da sua especificidade.

A emergência das OPNEs, com as características esboçadas, combinada com a revisão do papel do Estado, oferece a oportunidade de uma ampla experiência inovadora na relação entre o Estado e a sociedade civil na provisão de serviços públicos sociais ${ }^{35}$. Esta experiência poderia ser a fórmula de superar os entraves inerentes ao Estado Social Burocrático $^{36}$ - que provê serviços sociais de forma monopolista e ineficiente, através de um corpo de funcionários propenso a atuar em função de interesses particularistas — e as limitações do Estado Liberal, omisso na sua responsabilidade social.

\subsubsection{Aspectos vantajosos da terceira via}

As vantagens dessa nova via, em que o Estado financiaria as organizações públicas não-estatais que prestam serviços de educação, saúde, apoio à pesquisa e à cultura e assistência social, estaria na oportunidade de contar com maior eficiência, promover a competitividade e a flexibilidade na execução destas atividades. Ademais propiciaria um maior controle social.

Além desses, outros fatores, de interesse estratégico para os atores sociais, concorrem para uma maior participação das organizações públicas na provisão de serviços públicos. O Estado, levado pela crise fiscal e pelo esgotamento da sua capacidade operacional, abre a possibilidade de dividir suas tarefas com outros atores sociais. Os usuários começam a ver com esperança as alternativas de provisão de serviços, fora da via estatal, na expectativa de vir a ter serviços de melhor qualidade e efetividade na provisão. As organizações não-governamentais e comunitárias procuram aproximar-se dos governos, na busca de novas fontes de financiamento, face à redução da oferta de financiamento por parte dos parceiros tradicionais. A iniciativa privada interessa-se em executar apenas uma parcela muito restrita dos serviços sociais que permitem maximizar lucros. Os organismos internacionais favorecem as inversões de recursos públicos que envolvem as organizações públicas, porque as considera de retorno social mais seguro. 
Aos aspectos relevantes já vistos, deve-se adicionar fatores de sucesso associados à expansão das organizações públicas. O primeiro refere-se ao número expressivo de novas organizações que surgiram a partir de 1975 (Fernandes, 1994); em segundo lugar, a consistência que esse surto vem apresentando ao longo dos anos seguintes; em terceiro, a multiplicidade e pluralidade dessas organizações; em quarto, a tendência de aglutinação que elas apresentam (redes, federações, associações de abrangência nacional, alianças etc.); em quinto, a sua capacidade de criar uma arena própria de debate (fóruns, conferências, encontros); em sexto, a capacidade de articulação e interlocução interinstitucional ${ }^{37}$ (incluindo Estado, instâncias de representação política, sindicais, corporativas etc.); em sétimo, a capacidade de se organizarem como produtoras de bens e serviços ${ }^{38}$; por último, a capacidade de produzirem conhecimento e acúmulo de força política, que as habilita a exercer controle social sobre os demais atores da esfera pública.

Estas características poderiam, pelo menos em tese, vir a qualificar as organizações públicas não-estatais a se tornarem o elemento principal, através do qual a sociedade poderá organizar os serviços sociais de maneira competitiva e eficiente. Por seu lado, o Estado, através do financiamento e do controle dos resultados dos serviços prestados pelas organizações públicas, estaria se comprometendo com a garantia dos direitos sociais, de modo muito mais participativo e permeável ao controle social, do que na forma de provisão monopolista estatal ${ }^{39}$.

A seguinte colocação de Betina Levy (1996:3) dá uma boa dimensão da importância que os governos latino-americanos têm dado à parceria com as organizações públicas não-governamentais, na implementação da estratégia recomendada pelo Banco Mundial de enfrentamento da crise social, através dos fundos sociais.

"Los fondos han desencadenado un proceso de estrecha colaboración entre el Estado - es decir, gobiernos locales o municipales - y las ONGs y también constituyen pruebas de lo que debe ser la modernización de la administración pública y de la posibilidad de actuar como espacios de transferencia de experiencias a otros organismos."

Mas será que estas potencialidade não podem levar a que o Estado abandone sua responsabilidade pública, deixando de atuar em função da sociedade? A retração do Estado do seu papel de provedor direto poderá significar o enfraquecimento da sociedade civil, sobretudo da sua parte não-mercantil, ao reforçar a assimetria do poder na formação da agenda pública. Vista deste ângulo, a descentralização da provisão dos serviços sociais coloca a sociedade democrática diante do desafio de resolver como manter a responsabilidade do Estado frente ao interesse 
público, no momento em que este deixa de ter o vínculo direto com os direitos sociais. Nesta difícil travessia há duas dimensões a se considerar: aquela referente a ações dirigidas para a afirmação de direitos e ampliação da participação política nas decisões, e uma outra, de ações voltadas para a produção de bens e serviços públicos. As duas dimensões são inseparáveis e se alimentam de uma dupla relação com o Estado: de um lado, exigir o cumprimento de sua responsabilidade histórica, pressionando, opondo-se, numa relação de natureza conflituosa; de outro, substituindo-o na prestação de serviços sociais, colaborando, associando-se, numa relação de natureza solidária.

As mudanças em curso dependem, para que suas potencialidades possam ser canalizadas com sucesso, da criação de mecanismos de participação da sociedade civil na formulação, tomada de decisão e gestão de serviços e programas públicos. Trata-se de responder como transitar do estatal para o público, garantindo que a provisão de serviços públicos não dependa exclusivamente do Estado.

A convergência depende de que as expectativas sociais encontrem uma iniciativa do lado do Estado, tanto no que concerne à participação dos cidadãos, como na disposição de ampliar a sua influência na formulação das políticas, como na produção de bens públicos, reunidas em um modelo de ações complementares entre o Estado e a sociedade.

A permeabilidade ao controle social e à participação ampla da sociedade na gestão dos serviços públicos será fundamental para a defesa dos direitos associados a esses serviços; contra os ataques, por parte dos grupos privados e corporativos, ao patrimônio público (cultural, ambiental e econômico) e ao interesse coletivo. A finalidade de fortalecer a presença da sociedade civil no espaço público, é ampliar os benefícios das políticas públicas. Neste aspecto, a transparência efetiva dos negócios públicos é o instrumento mais eficaz contra os ataques aos direitos sociais. Outro aspecto positivo é a substituição da forma burocrática de administrar as coisas públicas por práticas gerenciais mais efetivas, eficazes e eficientes.

Neste sentido, vale a pena alinhar as características positivas das OPNEs que poderiam contribuir para o êxito da estratégia de aprofundamento da publicização, como forma inovadora de provisão de serviços sociais:

a) natureza concorrencial favorável a aumentar a oportunidade de escolha dos usuários, reduzir os custos dos serviços e incentivar a eficiência e melhoria da qualidade, a partir de uma vivência empreendedora, que as organizações desestatizadas não têm, e de um compromisso social que as organizações privadas não se propõem a ter;

b) multiplicidade de ofertas e uma melhor atenção para as especificidades das demandas, produzindo maior satisfação para os usuários e economia dos desperdícios decorrentes da oferta uniforme; 
c) modelo organizacional de características pós-burocráticas , inseridas em um sistema de avaliação de resultados, realizado pelas agências internacionais de financiamento; estruturas flexíveis, já adaptadas a trabalhar por objetivos e metas;

d) comprometimento das lideranças com o futuro das organizações, com seus princípios e missão; responsabilização dos dirigentes em função da democracia interna;

e) domínio dos espaços e da linguagem da participação política, produzindo menores áreas de atrito com os grupos desatendidos nos momentos de crise de oferta;

f) grande capacidade de articulação interorganizacional e interinstitucional, comprovada por anos de negociação de recursos escassos em ambiente de grande competitividade e de abrangência internacional;

g) ethos com características muito semelhantes àquelas originais do ethos do serviço público, ao qual se somam os valores da solidariedade, da tolerância, da democracia direta, e uma certa dose de austeridade e estoicismo.

\subsubsection{Problemas e desafios da estratégia de aprofundamento da publicização pela via das OPNEs}

O recuo do Estado como produtor direto de bens e serviços depende em grande medida do êxito das iniciativas da sociedade em substituí-lo de forma eficaz e duradoura. As organizações comunitárias e as ONGs contribuem para que se criem hábitos de auto-regulação e fortalecem a capacidade da sociedade de responder autonomamente aos problemas de interesse comum.

O enfoque na produção de serviços implica assumir de pronto um tipo específico de participação social e política. Uma participação, complementar com o Estado e portanto com o governo no poder, que pressupõe de algum modo estarem resolvidas as questões de participação no processo político e de formulação e tomada de decisões nas políticas sociais.

A experiência recente na América Latina contém, segundo Grau (1995), aspectos positivos representados pela participação, em casos particulares, mas não apresenta, no todo, um avanço significativo na formulação e decisões públicas. Certamente, a complementaridade na provisão das políticas e serviços públicos pressupõe muito mais do que reformas administrativas. Dependerá de toda a mudança política institucional mais ampla: a reforma política, a jurídica e a solução das questões político-administrativas.

As organizações comunitárias apóiam-se principalmente na solidariedade e na autogestão. Sua relação com o Estado é constitucionalmente 
fortuita. Uma relação permanente de base contratual com o Estado poderia significar sua desfiguração.

Para as ONGs mais estruturadas e mais dependentes de financiamentos externos para sua sustentação, o desafio está em manter sua vocação missionária organizadora, ao lado dos requerimentos da produção contínua de serviços públicos, e preservar sua flexibilidade frente às pressões mercantilizantes e de enrijecimento da sua organização interna. A ameaça que se coloca para as fundações públicas são as tentações de deslocamento dos compromissos públicos em direção à privatização, ao encastelamento e ao distanciamento do controle social ou estatal ${ }^{40}$.

$\mathrm{O}$ trade-off entre a necessidade de autonomia e a responsabilização pelo uso dos recursos públicos é um problema comum a qualquer forma de organização pública. Na medida em que novas organizações passarem a usar recursos públicos para atender as demandas sociais, muitos dos problemas apresentados pelas organizações burocráticas estatais tenderão a apresentar-se também nelas. Como evitar a captura de recursos públicos pelos grupos privados? Como delimitar a discricionariedade? Como evitar que se direcionem os recursos em proveito de grupos de interesse, ou em proveito da própria organização?

Outra questão fundamental é a de estabelecer os princípios de contratualização que devem reger a relação entre o ente financiador e os executores dos serviços. Estabelecer os critérios a partir dos quais serão feitas as avaliações de desempenho e resultado, as regras de transparência e publicidade, a pauta constitutiva da relação.

As perguntas que o novo arranjo sugere referem-se ao alcance que ele terá sobre a autonomização da esfera pública em relação à estatal e à privada. Será possível compartilhar o poder e as decisões? De que forma a associação entre o Estado e o terceiro setor poderá contribuir para reduzir a influência do patrimonialismo, do clientelismo e sanar as fraquezas burocráticas? De que forma poderá colocar barreiras à captura dos recursos públicos por interesses particularistas? Será possível criar uma nova cultura de co-responsabilidade política e social? Em que medida e em que condições? (Grau, 1995).

Não se pode perder de vista que o que estará sob exame é a possibilidade e a oportunidade de, por um lado, fortalecer a organização social e, de outro, ampliar a cobertura, a qualidade, a eficácia e a eficiência na prestação de serviços públicos sociais, com vistas a alcançar maior justiça social. As experiências conhecidas apontam para alguns problemas que aparecem com constância:

a) aumento dos custos, associado à melhoria da qualidade;

b) resistência burocrática empurrando as experiências para áreas periféricas e complementares; 
c) eficiência e efetividade comprovada quando a escala é pequena, a multiplicação das experiências com baixa taxa de sucesso;

d) custos de reprodução muito altos, associados ao caráter inovador e participativo;

e) tempo de maturação muito longo dos projetos novos;

f) dificuldade de manter padrão uniforme e de estabilizar a oferta;

g) dificuldade de dar sustentabilidade aos serviços;

h) tendência a criar relações assimétricas nos espaços de decisão, provocando, em decorrência, sua fragmentação;

i) dificuldade de manter a estabilidade dos organismos de gestão compartilhada.

Estes elementos reforçam a idéia de que é necessário promover mudanças institucionais e culturais no âmbito estatal, e um cuidado especial na definição e escolha das organizações públicas não-estatais para que a colaboração tenha resultados estáveis e duráveis. Implica fundamentalmente fortalecer as funções de regulação e coordenação do Estado. A opção por criar mecanismos e estratégias de associação entre as esferas estatal e pública, só se justifica social e politicamente se fundamentada em uma clara escolha política de descentralização de recursos, de autoridade e de responsabilidade do âmbito estatal para a sociedade autonomamente organizada. No fundo, trata-se de reconhecer no terceiro setor outro ator fundamental da sociedade, além do Estado e do mercado. Um setor que é heterogêneo como o mercado e por isso de natureza competitiva e criativa, e ao mesmo tempo é dirigido aos interesses do conjunto da sociedade como o Estado, e portanto, intrínseca e exclusivamente público, com identidade própria e maduro o suficiente para compartilhar das decisões e ações relacionadas com a satisfação dos direitos sociais.

A segunda decisão fundamental, a ser tomada pelas lideranças políticas, é relativa à importância estratégica do terceiro setor para o futuro desenvolvimento da sociedade. A crise dos anos 80 colocou em evidência os resultados positivos de investimento nas áreas sociais, apontados pelos especialistas, como um dos fatores decisivos para o excelente desempenho macroeconômico dos tigres asiáticos naquele período. A globalização veio potencializar ainda mais a importância dos gastos sociais em função da forte correlação entre melhorias na educação, saúde, na produção cultural e científica, e a produção de vantagens competitivas $^{41}$. Bernardo Kliksberg (1996) chama a atenção para documentos do Banco Mundial (Amartya Sen, 1996), que identificam os quatro tipos de capital com que as sociedades contam: os ativos naturais; os ativos produzidos pela sociedade; o capital humano formado pela população; e o capital social representado pelas instituições e pelos valores sociais. 
A questão em análise refere-se a dois dos quatro itens mencionados, o que não é nada desprezível, porque a sustentabilidade dos avanços econômicos depende de um correspondente desenvolvimento social ${ }^{42}$. Justifica inclusive a inversão do sinal das iniciativas de aproximação entre o Estado e as organizações da sociedade civil, quase sempre determinada pela dinâmica e vitalidade destas.

Uma decisão que venha importar em primazia estratégica à institucionalização e desenvolvimento do terceiro setor representaria um tipo de discriminação positiva, que deve ser considerada com muito cuidado. No modelo de regulação e coordenação reside o segredo de como superar os conflitos inevitáveis das organizações públicas entre si, e, sobretudo, destas com o setor privado. Trata-se de descobrir como evitar que os resultados positivos esperados corram o risco de serem anulados pelo esgarçamento do tecido social, decorrente dos embates entre os atores.

Outro cuidado importante refere-se à existência de organizações públicas que perderam ou venham a perder o sentido do interesse público, ao privilegiar, nas suas ações, relações clientelísticas com grupos específicos da sociedade, ou que se dobrem a ataques clientelistas dos órgãos estatais que as supervisionam, ou ainda ao ataque de interesses privados. Trata-se de reconhecer que a sociedade civil não é em si virtuosa, e que sob a capa da participação e da organização política da sociedade, podem perfeitamente estar bem escondidas práticas políticas retrógradas. Há que se considerar também os problemas intrínsecos dos processos participativos. Como observa Nassuno (1996:8), eles podem ter caráter cíclico decorrente da natureza imediatista das pressões reivindicativas, do que pode resultar a fragmentação dos laços entre as organizações públicas e os usuários. $\mathrm{O}$ problema aqui é que a falta de estímulo leve a OPNE à apatia, de uma forma muito mais intensa do que se entregariam organizações burocratizadas, menos imersas na sociedade e mais automáticas na ação.

Outro ponto delicado na regulação desse novo contrato social é a tensão entre as tarefas políticas das organizações públicas e a orientação para a produção de serviços públicos, destacada por Cunill Grau, ao analisar a questão. Esta nova contratualização implica o estabelecimento de parâmetros de produção de bens e serviços, que não podem deixar de ser cumpridos em função dos requisitos de eficiência e efetividade que se buscam alcançar na provisão social, e que fundamentam a opção estratégica pelas organizações do terceiro setor. A rigidez dos critérios de avaliação de desempenho organizacional contém uma contradição latente com os objetivos mais amplos das organizações públicas participativas, voltados para a mudança das relações sociais, cujos resultados são de difícil mensuração, e que sobretudo tendem a ser questionados pelas estruturas burocráticas estatais, na medida em que tocam na distribuição do poder e do produto social. 


\subsubsection{O novo papel do Estado frente a estratégia de aprofundamento da publicização}

Em relação ao papel do Estado colocam-se alguns desafios. O primeiro é que o processo de descentralização só pode ser responsabilidade do próprio Estado, que por isso terá de assumir totalmente suas conseqüências. A mais importante refere-se ao financiamento e à regulação das atividades descentralizadas. O segundo refere-se ao conteúdo da descentralização, sobre o qual não pode restar dúvidas, sob pena de fracasso. Caso se entenda que a opção política correta para a descentralização administrativa é através do terceiro setor, esta parceria/ associação deve-se expressar em algo mais dos que as relações contratuais. Neste caso, o terceiro setor deveria ser tratado como prioridade de governo, como instituição responsável pelo avanço social, não como um parceiro (eventual) de segunda classe, destinado a tarefas (complementares) menos nobres. Isto significa tratamento institucional; financiamento e regulação do próprio setor, além do financiamento e regulação das atividades que ele exerce.

Em decorrência destes dois desafios deriva um terceiro que os compreende e, por isso, é mais complexo. O respeito à autonomia e independência nos marcos da contratualização ${ }^{43}$ e da institucionalização, como condição de sobrevivência do novo arranjo entre o Estado e a sociedade. Um quarto desafio é o de combinar com os anteriores o princípio da corresponsabilidade, em que as organizações públicas nãoestatais aportam recursos, inclusive financeiros, em contrapartida aos recursos estatais. Da parte das organizações, implica assumir riscos e responsabilidade semelhantes aos das organizações privadas; da parte do Estado, o fomento e apoio a instituições privadas, cooperativas de crédito comunitário e similares, ou seja, reformar o sistema de financiamento das políticas sociais.

Outra ordem de questões é levantada pelo cenário descrito. Em muitas experiências de cooperação, as organizações públicas não-estatais foram levadas a subsidiar a provisão dos serviços acordados em razão de impedimentos e limitações burocráticas da parte estatal. Do outro lado da moeda, estão casos em que os recursos públicos foram desviados para finalidades estranhas ao objeto acordado, inclusive com a concordância dos eventuais beneficiários.

A solução desses problemas implica mudanças no aparelho burocrático do Estado e no seu marco regulatório. Como criar condições favoráveis para a atuação das organizações públicas não-estatais no novo marco de relações? Como assegurar a autonomia de um lado, e a responsabilização de outro? 
$\mathrm{Na}$ medida em que fornece recursos financeiros, o Estado deve colocar limites e regras para o uso dos recursos públicos pelas organizações públicas não-estatais. Além da transparência e coerência das regras e da necessária autoridade e competência específica das instituições de controle, é importante que se faça a revisão da institucionalidade regulatória, uma vez que nem as regras estatais, nem as regras aplicadas para o mercado, poderão ser simplesmente transplantadas para o espaço público não-estatal. Caberia a proteção legal dispensada às organizações estatais? Ou caberiam as puras regras da concorrência darwiniana? E nas relações de trabalho, valeriam regras especiais, do tipo das estatutárias, ou as quase universais do mercado, ou talvez outras mais flexíveis ainda?

O que estes comentários ressaltam é o fato de que a tendência futura é o tema da regulação tornar-se central nas relações do Estado com a sociedade. Talvez o caminho correto para enfrentar os dilemas do avanço social fosse o de começar redefinindo o marco regulatório em que a provisão de serviços sociais seria circunscrita, para então estabelecer as melhores estratégias visando atingir os resultados viáveis já definidos dentro da nova realidade institucional.

No plano das novas relações de poder interinstitucionais e interorganizacionais assoma como principal problema - o que parece ser uma característica típica das burocracias estatais - o de sistematicamente se opor a abertura do Estado à sociedade ${ }^{44}$, na medida em que esta mudança possa vir a afetar a maximização dos seus benefícios. Nessa hipótese, seria crucial a reforma institucional do aparelho do Estado como pré-condição para os novos contratos, compreendendo inclusive a revisão da concepção dominante de direito administrativo.

O que me parece indiscutível é que a constituição de uma esfera pública que venha a atuar em simetria com o Estado e o mercado, como uma possível solução duradoura e democrática para a produção de bens e serviços sociais através de organizações públicas não-estatais, passa a ser considerada como uma das principais tarefas teóricas e práticas, desafiando os atores sociais envolvidos com as questões da gestão pública. 
1 Esta alternativa tem duas modalidades: uma, que a identifica com a forma tradicional do Estado social-burocrático, tendendo a manter dentro do Estado a provisão de bens e serviços que o mercado pode oferecer com vantagens; e uma segunda, que é, na verdade, resultante do recuo das posições privatistas mais radicais ao perceber os perigos políticos da posição adotada, passam a usar estratégias de descentralização e focalização.

2 Esperava-se reduzir os gastos do Estado; entretanto as eleições pressionavam os governos conservadores a manter o nível de despesas com as políticas sociais.

3 Os EUA são o país em que esta via mais se generalizou. Sem que contudo se constitua numa forma institucionalizada de organizar a provisão de serviços sociais, mantémse um alto grau de espontaneidade na articulação e no financiamento dos programas implementados por ONGs e fundações.

4 O universo de organizações, que pertencem ao terceiro setor, é muito mais amplo do que o conjunto que será referido aqui. Conforme descreve Miguel Darcy de Oliveira, no prefácio ao livro de Rubens César Fernandes (1994), “um sem número de ações que visam ao interesse comum se desdobram ao norte e ao sul do planeta, em um terceiro setor — não-lucrativo e não-governamental".

5 Estes dados foram publicados no livro Privado porém Público do autor citado (1994).

6 "Dispomos de 32 diretórios referidos a 24 países da América Latina e do Caribe. O número total de ONGs existentes é certamente bem maior do que os diretórios apresentam." (Fernandes, 1994).

7 Associação Brasileira de Organizações Não-Governamentais. Os dados foram obtidos em entrevista com o presidente da ABONG, Silvio Caccia Bava.

8 O Parque Nacional da Serra da Capivara, o maior e mais importante sítio arqueológico brasileiro, onde se encontram os primeiros indícios da presença humana no continente americano, há mais de 40 mil anos, é administrado por uma organização nãogovernamental, a Fundação Museu do Homem Americano/Fundham.

9 Fato narrado por Bresser Pereira, Ministro da Administração e Reforma do Estado, em entrevista ao autor. Há uma referência, com menos detalhes, no texto "A reforma do Estado nos anos 90: lógica e mecanismos de controle"(Bresser Pereira, 1997).

10 Publicização refere-se à produção não-estatal de bens e serviços públicos, por entidades do terceiro setor. No Plano Diretor da Reforma do Aparelho do Estado do governo brasileiro, é a forma pela qual atividades não-exclusivas do Estado são transferidas para organizações não-estatais, sem implicar em privatização.

11 Além do efeito imediato sobre a população desatendida, já bastante grave em sí, pelo sofrimento e desigualdades que produz, a precarização dos serviços sociais, como os de saúde, educação, pesquisa e cultura, tem consequiências negativas mais amplas sobre a sociedade. Trata-se de perdas e retrocessos em relação aos aspectos redistributivos, as externalidades positivas, e ao avanço dos direitos da cidadania.

12 A descentralização da qual trataremos não tem uma expressão geográfica, mas macroorganizacional.

13 Estados Sociais, na classificação de Bresser Pereira, são: o Estado de Bem-Estar nos países desenvolvidos, o Estado Desenvolvimentista nos países em desenvolvimento, e o Estado Socialista, nos países socialistas. 
14 Na edição de 6 de agosto de 1997, Veja, a maior revista semanal brasileira, sumariza os principais tópicos do estudo de Armando Castelar Pinheiro, chefe do Departamento Econômico do BNDES, sobre o desempenho de 46 estatais. No artigo "No que deu, afinal, a privatização", apresentam-se os benefícios que a privatização trouxe para a Companhia Siderúrgica de Tubarão, a Rede Ferroviária Federal, a Light do Rio de Janeiro, a Companhia Siderúrgica Nacional / CSN, a Companhia Siderúrgica Paulista / COSIPA, Vale do Rio Doce, Acesita, Embraer e Usiminas.

15 No caso específico do Brasil, a economia é significativa dado que os salários dos servidores dessas áreas são muito superiores aos salários praticados pelo mercado.

16 Barzelay, em Breaking Through Bureaucracy, um dos livros fundadores da crítica ao modelo burocrático, questiona o insulamento e a autonomia da burocracia, o processo licitatório, o orçamento público e a legalidade processual. Esses fatores de impedimento de ações eficazes e eficientes afetam de forma mais aguda a provisão de serviços sociais, do que a formulação e a fiscalização, por causa da natureza competitiva da produção de bens sociais.

17 Um processo análogo e invertido ao que ocorreu quando o Estado interveio nos monopólios de serviços públicos, infraestrutura e indústria de base, por falta de investimentos privados capazes de enfrentar o desafio da industrialização.

18 No comentário de Abrucio (1997), verificamos que "Embora tenha surgido em governos de cunho neoliberal (Thatcher e Reagan), o modelo gerencial e o debate em torno dele não podem ser circunscritos apenas a este contexto. O modelo gerencial e suas aplicações foram e estão sendo discutidos em toda parte. Modelos de avaliação de desempenho, novas formas de controlar o orçamento e serviços públicos direcionados às preferências dos 'consumidores', métodos típicos do managerialism são hoje parâmetros fundamentais, a partir dos quais diversos países, de acordo com as condições locais, modificam as antigas estruturas administrativas."

19 Stiglitz (1996), analisando o comportamento do mercado frente aos bens públicos e privados, na perspectiva da Teoria do Bem-Estar, postula que a provisão privada de um bem público, cuja exclusão é possível e o custo marginal de provisão é zero, provoca a subutilização, perda de bem-estar e deadweight loss. E que o consumo de um bem privado exclui outro indivíduo de seu consumo.

20 É curioso notar que o nome dado pelos ingleses para a sua versão destas organizações é Quangos/Quasi Non Governamental Organizations. Veremos mais adiante que a denominação inglesa pode fazer mais sentido, do que os argumentos usados aqui permitem supor. Manuel Castells, na citação de Bresser Pereira, usa o termo organizações quase públicas para designar as ONGs, que seria um nome ainda mais apropriado para as organizações desestatizadas.

21 Voltando aos argumentos de Stiglitz (1996), veremos que em um mercado competitivo o equilíbrio de mercado é obtido no ponto em que a demanda iguala a oferta, o benefício marginal iguala os custos marginais e há eficiência econômica; e que o mercado competitivo, ou não oferta bens públicos, ou os oferta em quantidade insuficiente. Em relação às externalidades positivas (educação, saúde etc.) observa que quando elas vêm associadas a um bem, produz um ponto de equilíbrio muito baixo e resultados ineficientes.

22 Conforme comprovam as informações do livro Privado porém Público, de F.B. Fernandes (1994), "as ONGs tornaram-se um fenômeno massivo no continente, a partir da década de 1970. Cerca de 68\% surgiram depois de 1975."

23 "Cada vez mais, as agências internacionais de desenvolvimento dão preferência às ONGs na alocação dos seus recursos". (Entrevista com Silvio Caccia Bava, presidente da ABONG.) 
24 A partir do diagnóstico da crise da burocracia estatal, feito pelos intelectuais reformadores, a estratégia de publicização das organizações estatais deriva da finalidade de executar atividades de interesse público que não são exclusivas de Estado. Agências estatais encarregadas de prestar serviços sociais são transformadas, por iniciativa governamental, em organizações públicas não-estatais, com o objetivo de reduzir o déficit público, avançar na administração pós-burocrática e fortalecer o controle social.

25 "São instituições da sociedade civil que operam como corpos intermediários entre o Estado e as comunidades de base". Esta definição ressalta o caráter de intermediação das ONGs. Covarrubias destaca ainda a natureza alternativa das ONGs e o seu cunho ideológico de afirmação política, em contraposição às políticas oficiais.

26 Para Covarrubias os termos "não-governamental" e "alternativa" são infelizes por se referirem ao que as ONGs não são. Segundo ele, deveriam ser chamadas de "organizações privadas de desenvolvimento social".

27 Para Mantilla (1992:127), o nome ONG é inadequado porque enfatiza uma característica comum - estar fora do Estado — que não permite a definição operacional das organizações, por deixar o objeto excessivamente vago. Entretanto, aceita o fato que o nome já se disseminou e, bem ou mal, designa um fenômeno social emergente amplamente reconhecido.

28 Ou ONGs do Norte e ONGs do Sul

29 Nesta categoria caberiam todas as instituições privadas que, com ou sem fins lucrativos, dirigem suas atividades total ou principalmente para a prestação de serviços públicos, a exemplo das empresas prestadoras de serviços de saúde, seguro previdenciário, escolas de todos os tipos, laboratórios de pesquisa, instituições culturais.

30 Muitas ONGs nasceram devido à exclusão de alguns profissionais do âmbito público e universitário e pela necessidade de amparo político. Nos últimos anos, observa-se o ingresso voluntário de especialistas jovens e tecnicamente bem treinados nas ONGs, constituindo o que Chambers (1987) chama de novo profissionalismo. Em geral motivados por valores morais, filosóficos, religiosos ou políticos, estas pessoas buscam as ONGs para se realizar profissionalmente. Para Korten (CLAD, p.93) ao escolher as ONGs como meio de inserção no mundo do trabalho, profissionais vocacionados para o setor público buscavam evitar as formas burocráticas centralizadas das organizações estatais.

31 Segundo Korten (CLAD p.109), as organizações centralizadas, que dependem de controles burocráticos para canalizar o desempenho de seus membros em rotinas bem definidas, possuem um baixo nível de competência estratégica (competência estratégica é a medida da capacidade da organização de colocar seus recursos para atingir seus objetivos). Ao invés de fazer os ajustes nos recursos existentes, usam as novas demandas e oportunidades como meio para aumentar seu pessoal e orçamento, resultando em maiores custos e ineficiência.

32 Podemos dar como exemplos a educação de um grupo específico de uma determinada favela, em contraposição a um programa de educação para favelados. Ou ações de combate à fome em uma situação emergencial, em contraposição a programas de criação de emprego e renda nas periferias urbanas.

33 Ver Tendler, Judith. (1982), Turning Private Voluntary Organizations - PVO into development agencies.

34 Como registra Cernea (1992:18), alguns autores distinguem as ONGDs ( ONGs de desenvolvimento, voltadas para as necessidades dos setores de base), das OBs 
(Organizações de Base, constituídas por pessoas da base social), enquanto que outros (Uphoff,1986 ) sugerem a distinção entre "organizações de ajuda mútua para seus membros" e "organizações de serviço", em que, na primeira, os benefícios ficam restritos a seus membros, e, na segunda, a ajuda destina-se a terceiros. A tradição da literatura antropológica e sociológica define as associações voluntárias como "associações de interesse comum" (Kerri,1976).

35 Tarso Genro (1996) adiantou essa idéia no espaço público, por entender que a sociedade pode ter uma alternativa concreta para as privatizações na atuação das organizações públicas.

36 Segundo Bresser Pereira (1997), "O Estado tornava-se Social Burocrático na medida em que, para promover o bem-estar social e o desenvolvimento econômico, contratava diretamente, como funcionários públicos, professores, médicos, enfermeiras, assistentes sociais, artistas etc."

37 Peter Spink (1989) vê com preocupação a dificuldade institucional que as organizações estatais têm demonstrado em analisar e desenvolver as relações entre as diversas organizações, que contribuem na tarefa de desenhar e implementar políticas públicas, enquanto que organizações não-governamentais mostram grande desenvoltura neste aspecto.

38 Experiências envolvendo colaboração, contratação e outras formas de associação entre governos e organizações públicas contam-se aos milhares. Em questão de poucas horas, um telespectador atento pode tomar contato com elas. Para dar um exemplo concreto no dia 07/08/97, em meia hora, assisti a reportagens e entrevistas de dois projetos envolvendo parcerias, um da Caritas e outro da Favela Monte Azul, na Rede Vida e na TV Cultura, respectivamente. Essa citação pode não ser muito canônica, mas é comprovável.

39 Nuria Grau vê positivamente as mudanças em curso: "La "explosión" de iniciativas que hay en estos campos (das organizações públicas) pudiera servir para afirmar que hay en curso una transformación real de los modelos institucionales de prestación de servicios públicos, que no sólo asegura un mayor peso de la sociedad civil, sino una mayor calidade de los servicios, en el marco de una nueva institucionalidad pública."

40 Neste sentido, desempenha um papel muito importante o alerta de Bernardo Kliksberg (1996) sobre a necessidade de se preparar gerentes sociais para a prática de um estilo gerencial "adaptativo".

41 Lester Thurow (1996), preconiza o conhecimento, como sendo o fator decisivo na competição global.

42 James Wolfensohn (1996), presidente do Banco Mundial, em reportagem do Clarín, de Buenos Aires.

43 Para aprofundar este tema, há o trabalho de Marcelo de Matos Ramos sobre os contratos de gestão, no marco da reforma administrativa brasileira (1996).

44 Como bem observa Nuria Grau (1997), ao destacar que "el propio despliegue de la participación social encuentra uno de sus límites más importantes en la administración pública". 


\section{Referências bibliográficas}

Abrucio, Fernando L.. (1997), "O impacto do modelo gerencial da administração pública. Um breve estudo sobre a experiência internacional recente". Cadernos ENAP, Brasília, n.10.

Barreto, Maria Inês. (1996), "O modelo de Organizações Sociais e o Terceiro Setor," in Documentos , I Congresso Interamericano do CLAD / Centro Latinoamericano de Administración para el Desarrollo, Rio de Janeiro.

Barzelay, Michael. (1992), Breaking Through Bureaucracy. Berkeley: University of California Press.

Bresser Pereira, Luiz C.. ( 1997), “A reforma do Estado nos anos 90: lógica e mecanismos de controle". Cadernos MARE, Brasília, n. 1.

. (1996), “Administração pública gerencial: estratégia e estrutura para um novo Estado". Texto para discussão n. 9. Brasília: ENAP.

Bresser Pereira, Luiz C. \& Cunill, Nuria G.. (1997), Lo público no Estatal en el nuevo Estado del siglo XXI, CLAD, Caracas, mimeo.

Carvalho Neto, Antonio M. .(1996), “Terceirização dos serviços públicos no Reino Unido e os impactos sobre as relações de trabalho: considerações sobre a realidade brasileira". Revista do Serviço Público, Ano 47, v. 120, n. 2, mai-ago. Brasília: ENAP.

Cernea, Michael M. . (1992), "Organizaciones No-Gubernamentales y desarrollo local". Selección de documentos-clave, CLAD, v. 9, n.1.

Chambers, Robert. (1987), "Sustainable livelihoods, Environment and Development: Putting Poor Rural People First". Discussion Paper, n. 240. Sussex: Institute of Development Studies.

Covarrubias, Francisco. (1992), "Ampliando el concepto de lo no gubernamental”. Selección de documentos-clave, CLAD, Caracas, v. 9, n.1.

CunILL, Nuria G. .(1995), "La rearticulación de las relaciones Estado-Sociedad: en búsqueda de nuevos sentidos". Reforma y Democracia, CLAD, Caracas, n.4.

. (1997), "Lo Público. Articulaciones entre el Estado, la Administración Pública y la sociedad". Tese de doutorado defendida na Universidade de Caracas, mimeo.

Diniz, Eli. (1996), "Governabilidade, governance e reforma do Estado: considerações sobre o novo paradigma”. Revista do Serviço Público, ano 47, v.120, n.2. Brasília: ENAP.

Donahue, John D. . (1992), Privatização: fins públicos, meios privados. Rio de Janeiro: Zahar.

DRAIBE, Sonia. (1992), Brasil: o sistema de proteção social e suas transformações recentes. Campinas: Nepp/ Unicamp/Cepal, mimeo.

Evans, Peter. (1993), "O Estado como problema e solução". Lua Nova, n.28/29. São Paulo: CEDEC.

Esperança, Maria do Carmo T. . (1996), Organizações Sociais e Espaços Públicos nãoEstatais. Brasília: ENAP, mimeo.

Fernandes, Rubem C. . (1994), Público porém privado. Rio de Janeiro: CIVICUS, Relume-Dumará.

Ferreira, Caio M. M.. (1996), "Crise e reforma do Estado: uma questão de cidadania e valorização do servidor”. Revista do Serviço Público, ano 47, v.120, n.3. Brasília: ENAP. 
Jenkins, Kate. (1996), "Civil Service Reform in the United Kingdom”. Brasília: MARE, mimeo.

KaUfMan, Robert . (1997), "The politics of State Reform: a review of theoretical approaches", in Robert Kaufman. The political economy of administrative reform. Evanston, IL: Northwestern University.

KerRI, J.N.. (1976), "Studying Voluntary Associations as Adaptative Mechanismes: A review of Anthropological Perspectives", in Current Anthropology. London.

KLIKSBERG, Bernardo. (1996), "Hacia una gerencia social eficiente". Revista de Administração Pública. Rio de Janeiro: FGV.

(1996), "Repensando el Estado para el desarrollo social; más allá de convencionalismos y dogmas". Revista del CLAD, n. 7. Caracas.

Korten, David C.. (1987), "Micro Policy Reform: The Role of Private Voluntary Development Agencies, in Korten, D. (ed.). Community Management: Asian Experience and Perspectives". West Hartford: Kumarian Press.

Levy, Betina. (1996), Límites y oportunidades de la participación ciudadana en las políticas sociales", in Documentos, I Congresso Interamericano do CLAD. Rio de Janeiro.

Mare- Ministério da Administração e da Reforma do Estado. (1995), Plano Diretor da Reforma do Aparelho do Estado. Brasília: Presidência da República, Câmara da Reforma do Estado.

MantiLla, Fernando L.. (1992), "Las Organizaciones No-Gubernamentales y los sistemas locales de salud". Seleción de documentos clave, CLAD, v. 9, n.1.

Nassuno, Marianne. (1996), Comentários sobre a participação dos usuários nas Organizações Sociais. Mimeo. Brasília: ENAP.

Nathan, Richard P.. (1995), "Reinventing Goverment: What does it mean?". Public Administration Review, v.55, n.2.

Nogueira, Roberto M.. (1992), "Los pequeños proyectos: micro soluciones a macroproblemas ?". Seleción de documentos clave, CLAD, v. 9, n.1.

Norman, Richard. (1995), "New Zealand's Re-invented Government: Experiences of the Public Sector Managers". Public Sector, v. 18, n.2.

OszLAK, Oscar. (1996), "Estado y Sociedad: Las nuevas reglas de juego", in Documentos, I Congresso Interamericano do CLAD. Rio de Janeiro.

Portantiero, Juan C.. (1988), La produción de un ordem. Ensayos sobre la democracia entre el Estado y la sociedad. Buenos Aires: Ediciones Nueva Visión.

Przeworski, Adam. (1995), Reforming the State: Political Accountability and Economic Intervention. Conferência Inequality, the Welfare State and Social Values. El Escorial, Spain.

Ramos, Marcelo M.. (1996), Contratos de Gestão. Instrumentos de ligação entre setores do aparelho de Estado. Brasília: ENAP, mimeo.

RichARDSON, Ruth.. (1996), The New Zealand Public Sector Reforms. Seminário Internacional Reforma do Estado na América Latina e no Caribe. Brasília: MARE.

RothSCHILD-WHITT, Joyce. (1979), "The collectivist organization: An alternative to rationalbureaucratic models". American Sociological Review, v. 44. Ithaca: Cornell University.

Salamon, Lester \& Anheier, Helmut K.. (1992), "In search of Non- Profit Sector I: The Question of Definitions". Volutas 3/2. Manchester: Manchester University Press.

Salamon, Lester. (1996), Partners in Public Service. Baltimore: John Hopkins.

SHEPHERD, Geoffrey \& VALENCIA, Sofia. (1997), "Modernizando a administração pública na América Latina: problemas comuns, sem soluções fáceis". Revista do Serviço Público, v.120, n. 3. Brasília: ENAP.

SPINK, Peter K.. (1989), "Reforma Administrativa, modelos e processos". Executivo- FDRH, 12, 2. Porto Alegre. 
Stiglitz, Joseph E. (1996), Economics of the Public Sector. N.York: W.W. Norton \& Company.

Tendler, Judith. (1982), Turnig Private Voluntary Organizations into Development Agencies. Questions for Evaluation. AID Program Evaluation Discusson Paper, n.12. Washington, DC.

UphoFf, Norman. (1986), Local Institucional Development: An Analitical Sourcebook with Cases. West Hartford: Kumarian Press. 


\section{Nem privado nem estatal: em busca de uma nova estratégia para a provisão de serviços públicos \\ Carlos Antonio Morales}

A idéia que anima este artigo é a de juntar argumentos que demonstrem a importância de se reformar as relações do Estado com a sociedade para que a reforma do aparelho do Estado tenha sucesso. São discutidas as vantagens e desvantagens da provisão dos serviços públicos sociais por meio de organizações públicas não-estatais, como uma estratégia para superar a crise de governança do Estado contemporâneo e também como um caminho para reduzir a precariedade dos serviços sociais.

O esforço de superação da crise do Estado vem se traduzindo na redefinição do modo de financiamento e da maneira de organizar a execução das políticas públicas sociais, de forma a garantir efetividade na resposta às demandas sociais e maior eficiência na produção dos serviços.

A desestatização da provisão dos serviços sociais coloca as sociedades democráticas diante do desafio de resolver como manter a responsabilidade do Estado frente ao interesse público. Trata-se de responder como transitar do estatal para o público, garantindo que a provisão de serviços públicos não dependa exclusivamente do Estado, sem que este abandone seu papel de financiador e regulador das atividades de interesse geral.

O que não merece mais dúvidas é que a constituição de uma esfera pública que venha a atuar em simetria com o Estado e o mercado, como uma possível solução duradoura e democrática para a produção de bens e serviços sociais, através de organizações públicas não-estatais, passe a ser considerada como uma das principais tarefas teóricas e práticas que desafiam os atores sociais envolvidos com as questões da gestão pública.

\section{Ni privado ni estatal: en busca de una nueva estrategia para la provisión de servicios públicos \\ Carlos Antonio Morales}

La idea que anima este artículo es la que junta argumentos que demuestren la importancia de reformar las relaciones del Estado con la sociedad para que la reforma del Estado tenga éxito. Son discutidas las ventajas y desventajas de la provisión de los servicios públicos sociales a través de organizaciones públicas no estatales, como una estrategia para superar la crisis de gobernabilidad del Estado contemporáneo y también como un camino que reduzca la precariedad de los servicios sociales.

El esfuerzo para superar la crisis del Estado viene traduciéndose en la redefinición del modo de financiamiento y en la forma de organizar la ejecución de las políticas sociales, de modo que se garantice efectividad en la respuesta a las demandas sociales de mayor eficiencia en la producción de los servicios.

La desestatización de la provisión de los servicios sociales coloca a las sociedades democráticas ante el desafío de resolver cómo se mantiene la responsabilidad del Estado frente al interés público. Se trata de responder cómo transitar de lo estatal para lo público, garantizando que la provisión de servicios públicos no dependa exclusivamente del Estado, sin que éste abandone su papel de financiador y regulador de las actividades de interés general.

Lo que ya no merece ninguna duda es que la constitución de una esfera pública podrá actuar en simetría con el Estado y el mercado, como una posible solución duradera y democrática para la producción de bienes y servicios sociales, a través de organizaciones públicas que desafían a los actores sociales involucrados en la cuestión de la gestión pública.
Revista do

Serviço

Público

Ano 49

Número 4

Out-Dez 1998

Diretor de

Administração e

Finanças da

ENAP, mestre em

Administração

Pública pela FGV

São Paulo e

especilalista em

Políticas Públicas

e Gestão

Governamental 
Neither private nor state: in search for a new strategy for the provision of public services.

Carlos Anônio Morales

The idea behind this essay is to put together some arguments to demonstrate the importance of reforming the relationship between State and society, as a means of attaining a successful State reform. An analysis is made of the advantages and disadvantages of delivering social public services through public non-state organizations, as a strategy for overcoming the governance crisis of the contemporary State, as well as a way to reducing the poor quality of the social services.

The effort of overcoming the crisis has been put in action in the redefinition of the funding way and the way of organizing the implementation of social public policies, so as to ensure the effectiveness in responding to the social demands for a more effective service delivery. The desestatization of the delivery of social services forces democratic societies to face the challenge of keeping the State responsibility towards the public interest. It is a matter of finding a way of shifting from the state to the public, ensuring that the delivery of public services will not depend exclusively on the State, that shall keep its role of funding and regulation of the public interest activities.

It is unquestionable the need of a federal structure to act together with the State and the market, as a possible long-lasting and democratic solution for the delivery of social goods and services, through public organizations that challenge social actors involved with the public management. 